\title{
Pengarustamaan Gender Dalam Pengambilan Kebijakan Di Sekretariat Daerah
}

\author{
Salma \\ Darmawan Salman \\ Universitas Hasanuddin Makassar \\ darmawansalmanunhas@gmail.com
}

\begin{abstract}
ABSTRAK
Penelitian ini bertujuan untuk mengetahui Bagaimana Pengarustamaan Gender Dalam Pengambilan Kebijakan di Sekretariat Daerah Kabupaten Enrekang Kabupaten Enrekang. Tipe penelitian yang digunakan dalam penelitian ini adalah deskriptif kualitatif dengan dasar penelitian sumber.Teknik pengumpulan data menggunakan observasi, dokumentasi dan wawancara. Adapun yang menjadi populasi dalam penelitian ini adalah kepala Kantor Sekretariat Daerah Kabupaten Enrekang, Staf Dinas perekonomia dan pemerintahan, dari hasil penelitian menunjukkan bahwa peran pemerintah daerah dalam pemberdayaan masyarakat. Penelitian ini dilakukan dengan menggunakan metode penelitian deskriptif kualitatif.Dalam penelitian ini responden di pilih langsung oleh peneliti yang disebut sasaran penelitian. Pengumpulan data dalam penelitian ini dilakukan dengan cara observasi, wawancara, dan dokumentasi.Hasil penelitian di lapangan menunjukan bahwa pengawai memandang bahwa pengarustamaan gender dapat menberikan padangan bawah perempuan bisa menjadi seorang pemipin dalam sebuah perusahan dan pengarustamaan genden di kantor secretariat daerah bemberakan dapak posit bagus pada stap pegawai terutama kaum perempuan di Kantor Secretariat Daerah Kabupaten Enrekang karena dulunya perempuan dipandang sebelah mata seorang laki laki dalam pengabilan kebijakan dan perempuan juga bisa mendapatkan jambatan yang lebih tinggi dari pada laki-laki dan perempuan bisa juga menjadi seorang pemipin dalam sebuah kantor atau bisa juga menjadi presiden dan perempuan juga bisa mendapatkan pendidikan tinggi.
\end{abstract}

Kata Kunci : Pengarusutamaan, Gender, Kebijakan.

\section{PENDAHULUAN}

Silawati (2006:19) mengatakan pengarusutamaan gender (PUG) adalah strategi untuk mencapai kesetaraan dan keadilan gender.kesetaraan dan keadilan gender sendiri berarti adanya perubahan baik yang tangible (kasat mata) maupun intangible (tidak kasar mata) dalam kondisi dan relasi anatara laki-laki maupun dan perempuan.atau pengarusatamaan gender (gender mainstreaming), yaitu merupakan salah satu starter penbanguna yang digunakan pemerintah dalam upaya memperkecil/menghilangkan isu kesetaraan gender di berbagai bidang pembangunan atau Gender merupakan suatu konsep. Mencuatnya gender merupakan salah satu perjuangan atas diskriminasi terhadap perempuan, kontruksi sosial masyarakat sering menempatkan perempuan pada urutan 
nomor dua, perempuan yang dianggap kaum yang lemah dan ini merupakan titik rawan untuk pendiskriminasian, eksploitasi, maupun bentuk kekerasan. Permasalahanpermasalahan tersebut bukanlah hal yang wajar untuk terus dipertahankan, selain merugikan kaum perempuan juga salah satu penyebab timbulnya ketimpangan dalam pembangunan di daerah maupun nasional. Untuk meminimalkan permasalahan ketimpangan dalam bidang pembangunan di daerah, dan guna mendorong kesetaraan gender menuju keadilan gender maka perlu upaya pengintegrasian peran gender dalam tatanan keluarga maupun birokrasi dan lembaga lainya, laki-laki dan perempuan mempunyai kesempatan dan peluang yang sama dalam berkontribusi terhadap kegiatan pembagunan daerah, itu salah satu strategi mewujudkan kesetaraan dan keadilan gender, oleh pemerintah telah menetapkan peraturan dalam bentuk instruksi presiden nomor 9 tahun 2000 tenteng pengarustamaan gender.

Pengarustamaan gender di Kabupaten Enrekang sudah terlihat pada Pelantikan Kepala Desa Perempuan Pertama di Enrekang pada tahun jarurai 19,2012. pemberdayaan perempuan pada tahun februari 22,2012 pada hari HUT kabupaten Enrekang ke 52menggelorakan kembali pembangunan dan kaun perempuan dan anak.harapan ini dikemukakan anggota DPRD kabupaten Enrekang Masna S. Si, Apt. Masna,dalam setiap laporan kemajuan pembangunan hampir tidak pernah menyinggung atau menyebut pembangunan dan pemberdayaan perempuan dan anak.

Kabupaten Enrekang yang selama ini juga sering mencanangkan struktur yang dikecilkan, namun harus memperbanyak fungsi hanyalah sebagai wacana saja, sedangkan pelaksanaanya selalu saja berpedoman dengan ketentuan pusat. Pada masa sekarang ini, yaitu era otonomi kabupaten Erekang mulai berbenah diri dengan tekad yang bulat untuk mempergunakan kesempatan luas yang ada sekarang dalam pembenahan lembaganya. Berdasarkan Peraturan Daerah Kabupaten Enrekang Nomor 3 tahun 2008 tentang Pembentukan Susunan Organisasi dan Tata Kerja Sekretariat Daerah Kabupaten Enrekang mempunyai tugas dan kewajiban membantu Bupati dalam menyusun kebijakan dan mengkoordinasikan Dinas Daerah dan Lembaga Teknis Daerah dan pelaksanaan tugas lain yang diberikan oleh Bupati sesuai dengan tugas dan fungsinya.Adapun urusan tersebut dilaksanakan oleh Bagian Organisasi, lebih lanjut disebutkan, bahwa Bagian Organisasi Sekretariat Daerah Kabupaten Enrekang bertugas melaksanakan penyusunan pedoman dan petunjuk teknis pembinaan kelembagaan, ketatalaksaan, dan Pengembangan analisis jabatan, mekanisme kerja serta perangkatnya. Namun semuanya itu berpedoman pada aturan pusat yang selama ini bersifat sentralistik, sehingga dalam 
pelaksanaan pekerjaan sehari-hari terlihat masih banyak tumpang tindih pekerjaan antara satu bagian dengan bagian lainnya, koordinasi yang tidak terlaksana dengan baik.

Pengambilan keputusan atau kebijakan sebagai bentuk salah satu peningkatan kinerja Organisasi dalam hal ini sekeriat daerah Kabupaten Enrekang. Yang menurut hasil survey awal pengambilan kebijakan tersebut lebih dominan laki-laki daripada perempuan dengan melihat indikator dominasi pejabat laki-laki daripada perempuan, sehingga itulah yang menyebabkan penulis mengangkat judul "Pengarustamaan Gender Dalam Pengambilan Kebijakan Di Sekretariat Daerah Kabupaten Enrekang”.

\section{KAJIAN TEORI}

Pengarusutamaan Gender (PUG), sebuah konsep yang diadopsi dari Konferensi Perempuan sedunia ke-4 di beijing (1995), secara global telah diteriman sebagai strategi dan pendekatan untuk mewujudkan kesetaraan dan keadilan gender dalam pembangunan.Target dari Pengarusutamaan Gender ini adalah agar kebijakan dan Program/kegiatan yang dihasilkan oleh pemerintah menjadikan gender sebagai arus utama,sehingan sebelum keputusan diambil,terlebih dahuluh dibuat analisis yang berkaitan dengan dampak kebijakan/ Program/ kegiatannya terhadap perempuan dan laki-laki. Di Indonesia, istilah gender mainstreaming mulai popular setelah muncu, PUG adalah telah diadopsi secara resmi di Indonesia sejak tahun 2000 dengan keluarnya Instruksi Presiden atau Inpres No. 9 tahun 2000. Kemunculan dasar hukum ini merupakan satu bentuk komitmen pemerintah Indonesia untuk mengikuti kesepakatan internasional, serta desakan masyarakat sipil agar pemerintah melakukan tindakan-tindakan konkrit dan sistematis dalam mewujudkan kesetaraan dan keadilan gender.

Dalam kehidupan sehari-hari sering dipermasalahkan tentang pekerjaan laki-laki dan perempuan yang diharapkan sesuai degan kodratnya.Pandangan masih berkisar pada faktor biologis dimana perempuan yang berbadan lemah seyogyanya mendapat pekerjaan yang ringan sedangkan pria yang fisiknya kuat semestinya mendapat pekerjaan yang lebih menampilkan kakuasaan. Pandangan semacan ini tidak dapat dipertahankan karena dalam berbagai penelitian dibuktikan bahwa mampu memiliki keterampilan, kecerdasan dan melakukan berbagai tugas. Sebaliknya banyak pria yang memilih pula pekerjaanpekerjaan "feminim".

Nugroho (2008: 60) kesetaraan gender dapat juga berarti adanya kesamaan kondisi bagi laki-laki maupun perempuan dalam memperoleh kesempatan serta hak- 
haknya sebagai manusia agar mampu berperan dan berpartisipasi dalam kegiatan politik, hukum, ekonomi, sosial budaya, pendidikan, dan pertahanan \& keamanan nasional (hamkamnas) serta kesamaan dalam menikmati hasil pembangunan. Terwujudnya kesetaraan dan keadilan gender ditandai dengan tidak adanya diskriminasi antara perempuan dan laki-laki sehingga dengan demikian antara perempuan dan laki-laki memiliki akses, kesempatan berpartisipasi, dan kontrol atas pembangunan serta memperoleh manfaat yang setara dan adil dari pembangunan.

Pemahaman orang terhadap gender ini masih banyak yang salah interpretasi yang hanya melihat dari satu sisi, yakni ketika kita berbicara gender maka yang berhak adalah kaum perempuan karena didalam pembahasan gender ini kaum perempuanlah yang merupakan tema sental, artinya selalu kaum perempuan memiliki porsi banyak dalam pembahasan tersebut. Padaha gender ini adalah merupakan miliknya juga kaum laki-laki. Inilah yang membuat sebagian orang salah interpretasi terhadap gender, sehingga sipil efeknya juga terimbas kepada kaum perempuan.Mengapa pengungkapan masalah kaum perempuan dengan menggunakan analisisgender sering menghadapi perlawananbaik dari kalangan kaum laki-laki maupun perempuan sendiri.Tidak hanya itu, analisis gender justur sering ditolak oleh mereka yang melakukan kritis terhadap system sosial yang bersifat kapitalisme.Kadang diantara kita tidak dapat membedakan antara sex dan gender. Banyak kalangan menganggap bahwa gender dan sex tidak berbeda. Keduanya mengandung arti yang sama yakni jenis kelamin. Jauh dari apa yang sudah terlanjur dituduhkan banyak orang mengenai isu gender selama ini. Sesungguhnya dikursus gender mempersoalkan terutama hubungan sosial, kultural, hukum dan politik antara laki-laki dan perempuan. Konsep gender sendiri sebetulnya sangat sederhana walau ia sering dikaburkan dengan pengertian jenis kelamin. Masyarakat umumnya mengidentifikasikan gender degan jenis kelamin (sex). Sebagai langkah awal perlu ditegaskan bahwa isu gender tidak dapat dipisahkan dari variabel jenis kelamin, bahkan gender secara sosiologis berawal dari perbedaan jenis kelamin. Jenis kelamin adalah konsep biologis sebagai identitas kategorial yang membedakan laki-laki (jantan) dan perempuan (betina).

Identitas jenis kelamin dikonstruksikan secara ilmiah, kodrati yang merupakan pemberian distingtif yang kita bawa sejak lahir.Akibatnya, jenis kelamin bersifat tetap, permanen, dan universal. Sedangkan gender adalah seperangkat atribut dan peran sosialkultural yang menunjukkan kepada orang lain bahwa kita adalah feminim atau maskulin. Tidak seperti jenis kelamin yang bersifat kodrati, gender dikonstruksikan secara sosial maupun kultural melalui proses sosial yang sangat dinamis. Sesuai dengan asal usulnya, 
pembentukan gender didasarkan pada espektasi nilai-nilai sosial dan kultural.Oleh sebab itu, gender dapat berubah (changetable) sewaktu-waktu seiring dengan perubahan dimensi ruang dan waktu. Konsep gender yakni suatu sifat yang melekat pada kaum lakilaki maupun perempuan yang dikontruksi secara sosial maupun kultural, sehinggagender dipengaruhi dan dibingkai oleh banyak hal dan komponen determinatifnya sangat variatif seperti nilai-nilai budaya, tradisi agama, sosial dan sistem politik. Gender di konstruksi baik sengaja maupun tidak dan disosialisasikan pertama kali melalui institusi keluarga, lingkungan sosial dan sekolah dan kemudia dicarikan dasar penopang ideologisnya untuk menguatkan jenis perbedaan tersebut.Dalam kaitan diatas, teks dan doktrin keagamaan sering dijadikan sebagai tempat berlindung dan acuan utama untuk merumuskan pemikiran diskusif tentang gender. Fakih (2013: 8) mengungkapkan artikulasi gender adalah perbedaan perilaku (behavioral differos)antara laki-laki dan perempuan yang dikonstruksi secara sosial yakni perbedaan yang bukan kodrat atau bukan ketentuan Tuhan melainkan diciptalan oleh manusia (laki-laki dan perempuan) melalui proses sosial dan kultural yang panjang.

Gender adalah suatu konsep yang digunakan secara umum yang dapat dfidefinisikan sebagai suatu kultural yang membedakan maskulin (laki-laki) dan feminisme (perempuan). Dipandang dari segi sosial budaya dan gender dapat didefinisikan perbedaan laki-laki dan perempuan dari sudut non biologis yang merupakan bantukan sosial yang dapat berubah-ubah dan dapat berbeda-beda tergantung dari kondisi sosial, budaya dan agama.Peran laki-laki dan perempuan sangat diperlukan dalam kehidupan publik, sehingga untuk pelaksanaannya diperlukan kebijakan publik yang bisa melindungi peranan perempuan.

Frienrich dalam Budi Winarno (2007) mengatakan kebijakan publik adalah suatu arah tindakan yang diusulkan seseorang, kelompok, atau pemerintah dalam suatu lingkungan tertentu, yang memberikan hambatan-hambatan dan kesempatan-kesempatan terhadap kebijakan yang diusulkan untuk menggunakan dan mengatasi dalam rangka mencapai suatu tujuan, atau merealisasikan suatu sasaran atau maksud tertentu.

Sekretariat Daerah Kabupaten/Kota merupakan unsur pembantu pimpinan pemerintah kabupaten/kota yang dipimpin oleh secretariat daerah, berada di bawah dan bertanggung jawab kepada Bupati/Walikota.Sekretariat daerah kabupaten/kota bertugas membantu bupati/walikota dalam melaksanakan tugas penyelenggaraan pemerintahan, administrasi, organisasi dan tata laksana serta memberikan pelayanan administrasi kepada 
seluruh perangkat daerah kabupaten/kota.sekretariat daerah untuk kabupaten/kota diangkat dan diberhentikan oleh Gubernur atas usul bupati/walikota.

Jenis penelitian yang dilakukan penelitian kualitatif yang bertujuan memahami pengarusutamaan genderdi Secretariat Daerah Kabupaten Enrekang. Instrumen penelitian adalah peneliti sendiri dan alat bantu yang lain. Informan penelitan adalah pegawai kantor sekretariat yang memiliki posisi tertinggi sampai yang terendah.Sumber data penelitian terdiri dari data primer dan data sekunder.Teknik pengumpulan data yaitu observasi, wawancara dan dokumntasi, kemudian dianalisis melalui mencatat data, mengumpulkan, berpikir dan menggunakan teknik keabsahan data triangulasi metode, pengamat dan data.

\section{PEMBAHASAN}

1) Pengarustamaan Gender dalam pengambilan kebijakan di Sekretariat Daerah

\section{Kabupaten Enrekang}

Hal penting yang perlu diingat bila kita membahas soal kebijakan publik, secara normatif ini artinya kita sedang berbicara tentang peranan pemerintah dalam menentukan kualitas kehidupan masyarakat. Meskipun demikian, pernyataan ini dianggap kontroversial, sebab masyarakat bisa jadi menganggap bahwa pemerintah sesekali bukan menyelesaikan masalah tetapi justru membuat atau menambah masalah baru.Akan tetapi, lepas dari argumentasi tersebut, kebijakan publik memang mempengaruhi kehidupan masyarakat, termasuk kehidupan masyarakat perempuan di dalamnya. Demikian juga sebaliknya, banyak perubahan-perubahan yang telah dicapai perempuan dalam kehidupannya sehingga pada gilirannya akan mempengaruhi pula kebijakan publik. Oleh sebab itu, perubahan dalam kebijakan publik harus memperhitungkan nilai-nilai, keyakinan dan budaya yang dianut uang yang mempengaruhi kehidupan perempuan.

Pembangunan diarahkan untuk dapat meningkatkan kualitas hidup dan kehidupan rakyat.Keberhasilan pembangunan secara sederhana dapat diukur berdasarkan indikator perbaikankondisi ekonomi, kemudahan mengakses layanan pendidikan dan peningkatan kualitas kesehatan bagi segenap lapisan masyarakat.Inpres No, 9/2000 mengenai pengarusutamaan gender (PUG) mengemukakan bahwa PUG adalah: "suatu strategi untuk mencapai kesetaraan gender melalui kebijakan publik. PUG merupakan suatu pendekatan untuk mengembangkan kebijakan yang memasukkan pengalamanpengalaman dan permasalahan-permasalahan perempuan dan laki-laki ke dalam perencanaan, pelaksanaan, pemantauan dan evaluasi kebijakan dan program dalam bidang-bidang politik, ekonomi, dan kemasyarakatan.Kebijakan publik sebagai suatu 
rangkaian kegiatan atau langkah tindakan, didalamnya terdapat proses yang divisualisasikan sebagai serangkaian tahap yang saling bergantung yang diatur menurut urutan waktu.

Dari hasil penelitian menunjukan bahwa pengambiloan kebijakan di Sekretariat Daerah Kabupaten Enrekang membagi dalam 4 (empat) tahapan, yakni:

a) Pengarustamaan gender dalam perencanaan kebijakan

Dalam mendorong pembagunan yang responsif gender di sekretariat Daerah Kabupaten Enrekang, selain membangun jaringan secara sosial di tengah masyarakat, sekretariat daerah selaku organisasi peerintah juga melakukan intervensi kepada peyelenggaraan pemerintah. Dalam hal ini instansi yang terkait dalam sejumlah aspek pembagunan seperti bidang kesehatan, pendidikan, dan badan perencanaan pembagunan daerah, Dinas PU, dan lain sebagainya.

Dengan adanya pengarystamaan gender dalam pengambilan kebijakan di suatu instansi yakni di sekretariat daerah kabupaten enrekang maka keterlibatan laki-laki dan perempuan sangat di harapkan karena di dalam perencanaan sebagai suatu kebijakan publik merupakan proses kegiatan usaha yang dilakukan secara terus menerus dan komprehensif serta memiliki tahapan sistimatis sehingga di dalam merencanakan sebuah kebijakan itu bisa berjalan dengan baik dan dapat di terima oleh semua pegawai pemerintahan yang ada pada sekretariat daerah kabupaten enrekang,

b) Pengarustamaan gender dalam penyusunan kebijakan

Dalam sebuah penyusunan sebuah rencana kebijakan bisa di lakukan bersama-sama antara laki-laki dan perempuan yang memiliki tinjauan keaadaan, baik sebelum memulai rencana, maupun tinjauan terhadap pelaksanaan rencana sebelumnya.

Bebebrapa perkiraan keadaan masa yang dilalui rencana (forecasting), penetapan tinjauan rencana (plan objektives) dan pemilihan cara-cara pencapain tujuan rencana, identifikasi kebijakan atau kegiatan usaha yang perlu dilakukan dalam rencana serta pengambilan keputusan sebagai persetujuan atas semua rencana, tetapi itu belum efektif karena di sekretariat daerah kabupaten enrekang masih di dominasi oleh kaum laki-laki,

c) Pengarustamaan Gender dalam Pelaksanaan Kebijakan

Sekretariat Daerah Kabupaten Enrekang dengan adanya pengarustamaan gender maka perempuan dan laki-laki dilibatkan dalam pelaksanaan kebijakan karena melihat potensi-potensi yang dimiliki sehingga dalam hal ini kebijakan yang sudah ada perlu diikuti pelaksanaannya, bahkan secara terus-menerus memerlukan penyesuaian, sehingga pelaksanaan kebijakan tersebut 
d) Pengarustamaan Gender dalam Evakuasi Kebijakan

Dengan adanya perencanaan, penyusunan, pelaksanaan kebijakan maka tiga hal tersebut harus di evakuasi karena evaluasi bartujuan untuk membantu kegiatan pengawasan yang dilakukan melalui suatu tinjauan yang berjalan secara terus menerus (concurrent review) walaupun ada tantangan yang menjadi permasalahan harus dihadapi Di sekretariat Daerah Kabupate Enrekang hanya saja ini dibenturkan dengan pemahaman budaya seperti yang diungkapkan diatas. Dalam pengambilan kebijakan tidak melihat dari jenis kelamin akan tetapi berdasar pada kompetensi yang dimiliki oleh setiap manusia.

2) Faktor yang mempengaruhi pengarustamaan gender dalam pengambilan kebijakan

a) Budaya patriaki

Masyarakat/etnis Makassar meyakini bahwa yang menjadi faktor yang mempengruhi pengarustaman gender dalam pengambilan kebijakan di Sekretariat Daerah Kabupaten Enrekang adalah adanya aturan sosial yang telah di letakan secara tradisional kepada kedua jenis kelamin. Misalnya : mangajarkan bahwa berkelahi lebih cocok untuk laki-lai dari pada perempuan, orang tua memberikan yang berbeda kepada anak laki-laki dan perempuan, misalnya memberikan anak laki-laki senjata-senjataan dan boneka untuk anak perempuan, orang tua lebih setuju jika yang berperilaku agresif adalah anak lakilaki daripada anak perempuan (Sainal Zaid 2009).Sehingga pembelaan negative (stereotipe) terhadap jenis kelamin tertentu dan akibat terjadinya diskriminasi serta terjadinya berbagai ketidakadilan itu terlihat dalam masyarakat karena banyak sekali pembelaan negative sehingga mengakibatkan kaum perempuan memiliki batasan, menyulitkan memiskinkan, dan merugikan kaum perempaun itu sendiri.

b) Tingkat pendidikan

Pada Zaman sekarang pendidikan sangat penting untuk menunjang masa depan yang lebih baik, tetapi pada kenyataanya masih banyak anak bangsa yang tidak bisa mendapatkan pendidikan yang layak, banyak anak-anak yang sudah bekerja karena keterbatasan ekonomi, padahal kita ketahui anak-anak itu adalah generasi untuk kedepanya.

\section{KESIMPULAN}


1) Pengambilan kebijakan di Sekretariat Daerah Kabupaten Enrkang adalah kebijakan publik merupakan proses kegiatan usaha yang dilakukan secara terus menerus dan konprehensif serta memiliki tahapan yang sistematis.

2) Pengarustamaan Gender dalam pengambilan kebijakan di Sekretriat Daerah Kabupaten Enrekang, kaum perempuan lebih relative sedikit pemegang kebijakan jika dibandingkan dengan kaum laki-laki. Padahal dalam pengambilan kebijakan tidak melihat dari jenis kelamin akan tetapi berdasar pada kompetensi yang dimiliki oleh setiap manusia.

3) Faktor-faktor yang mempengaruhi pengarustamaan gender dalam pengambilan kebijakan antara laki-laki dan perempuan di Sekretriat Daerah Kabupaten Enrekang yakni : adanya pemahaman budaya yang menguntungkan kaum laki-laki, dan faktor Pendidikan

\section{DAFTAR PUSTAKA}

Fakih ,DR.Mansour, (2013). Analisis Gender \& Transpormasi Sosial, Pustaka Pelajar: Yogyakarta.

Saptiawan, Itsnahadi, (2007). Gender \& Inferioritas Perepuan, Pustaka Pelajar: Yogyakarta.

Suyanto,Bagong, (2004). Teks Pengantar, \& Terapan,Pustaka Pelajar:Jakarta

Illich, Ivan. (1983).Gender.London:Marion Boyors.

Ihromi, T.O, (1995). Kajian Wanita Dalam Pembangunan, Yayasan Obor indonesi : Jakarta.S

Ihromi, T.O, (2007). Pusat Kajian Wanita dan Gender Universitas Indonesia, Hak Azasi Perempuan,,(Instrumen hukum untuk mewujudkan keadilan gender), Yayasan Obor indonesi : Jakarta.

Lindsey, Linda L, (1990). Gender Roles: Sociological Perspective, New Jersey: Prentice Hall.

Megawati,Ratna, (1999). Membiarkan Berbeda:Sudut Pandang Baru Tentang Relasi Gender, Penerbit Mizan.

Mosse,Julia Cleves, (2007). Gender \& Pembangunan, Pustaka Pelajar: Yogyakarta.

Musda,Siti Mulia, (2003). Keadolaan Dan Kesetaraan Gender(Perspektif Islam), LKAJ: Jakarta.

Mustari, Nuryanti, (2013). Implementasi Kebijakan Publik (Pemahaman Teoritis Empiris), Membumi Publishing: Makassar. 
Nugroho Riant, (2008). Gender dan Administrasi Publik, Pustaka Pelajar: Yogyakarta.

Subarsono, (2005).Analisis Kebijakan Publik, Pustaka Pelajar: Yogyakarta.

Wahid, Zani Rahman, (1999). Memposisikan Kodrat Perempuan dan Perubahan dalam Persfektif Islam. Mizan: Bandung.

Winarno,Budi, (2007). Kebijakan Publik Teori dan Proses, Media Pressindo: Yogyakarta.

Peraturan Daerah Kabupaten Enrekang Nomor 3 Tahun (2008) Tentang Pembentukan Susunan Organisasi dan Tata Kerja Sekretariat Daerah Kabupaten Enrekang. 